\title{
Examination of Entrepreneurship from Humanistic Values Perspective
}

\author{
Ercan Yilmaz ${ }^{1,2}$ \\ ${ }^{1}$ Educational Sciences Department, Necmettin Erbakan Universitiy, Konya, Turkey \\ ${ }^{2}$ Educational Sciences Department, Education Faculty, N. E. University, Konya, Turkey \\ Email: ercanyilmaz70@gmail.com \\ Received April 10 $0^{\text {th }}, 2013$; revised May $14^{\text {th }}, 2013$; accepted May $29^{\text {th }}, 2013$
}

Copyright (C) 2013 Ercan Yilmaz. This is an open access article distributed under the Creative Commons Attribution License, which permits unrestricted use, distribution, and reproduction in any medium, provided the original work is properly cited.

\begin{abstract}
This study attempts to examine the influence of humanistic values people prefer on their entrepreneurship. The study is a qualitative study and the data were collected and analyzed using this method. Besides, relational screening model was used. The study group is composed of 482 students who were selected with random sampling method among students who attended various faculties at Selçuk University in 2012. In the study, Schwartz List of Values was used to measure individuals' value preferences in their lives. Entrepreneurship Scale, which was developed by Yılmaz and Sünbül (2009), was used to measure their entrepreneurship tendency. In the study, it was revealed that there is a significant relation between humanistic values people prefer and entrepreneurship and, humanistic values explain entrepreneurship tendency.
\end{abstract}

Keywords: Component; Entrepreneurship; Humanistic Values; Schwartz List of Values

\section{Introduction}

The most fundamental asset of societies is their human resource and the most important human quality is entrepreneurship. The word entrepreneur, made up of the words "entre" (to enter) and "prendre" (take over), means "building something" (Öğüt, 2006: p. 431). Entrepreneurship can be defined as the general name given to innovation, risk taking, seeing opportunities and carrying them into practice. Entrepreneurship was defined in many different ways. Some of them are as follows:

- Entrepreneurship is a process by which people pursue opportunities, fulfilling needs and wants through innovations and active handling of risks and uncertainties, without regard to the resources they currently control (Robbins \& Coulter, 1999).

- Entrepreneurship is the name given to all the processes of risk taking, pursuing opportunities, actualization and innovation (Çetindamar, 2002: p. 34).

It is seen that three components are of significance in entrepreneurship. First, taking initiative; second, the effective use of resources by organizing economic and social conditions; and the third is the acceptance of failure and risk (Karahan \& Ulusoy, 2010). It is stated that entrepreneurs have three fundamental characteristics: "vision", "mission" and "ambitiousness" (Smilor-Sexton, 1996: pp. 7-9). Besides, being innovative, having a vision, craving for success, being able to do internal auditing, being able to bear uncertainties, creating values and directing transformation are among the characteristics of entrepreneurship (Turan \& Nacimudinova, 2006: p. 352). In addition to these characteristics, the outstanding personality characteristics that psychodynamic and socio-psychological approaches emphasize are "pro-activity", "dynamism", "purposefulness", "positivity" and "taking initiative". Besides, "innovativeness", "imaginativeness", "creativeness", "flexibleness" and so on are underscored as qualities that define entrepreneur identity. In addition, "being agreeable", "having a feeling of trust", "taking reasonable risks", "being decisive" "being willful", "having result-driven intellectual capacity and high self-confidence" are among the characteristics mentioned (Bridge et al, 1998: p. 43).

The competencies entrepreneurs have are examined under three main categories: technical, organizational and personal. The interpersonal relation, which is one of the technical competencies, draws attention as a concept which has gained prominence recently. While organizational competencies include characteristics an administrator needs to have, among personal competencies risk taking, making innovation and managing change are the outstanding basic determiners (Hisrich \& Michael, 1998). In addition to them, entrepreneurship competencies are composed of self-confidence, being willing to take responsibility, generate innovative and creative ideas to deal with problems, addressing uncertainties and taking risks. These competencies and attitudes influence individual's success in social life as much as his/her success in business life (Ofsted-Better Education and Care, 2005). Iredale and Motsa (2002) list entrepreneurship competencies as follows: problem solving, creativeness, persuasiveness, planning, making right decisions, having self-confidence, being autonomous and self-sufficient, gravitating success, being versatile and dynamic. Entrepreneurs can be defined as individuals who make a positive difference in the procession of an existing condition in any environment or in any role they take over.

In studies on this issue, it was pointed out that entrepreneurship intention was influenced by the obstacles and support factors people perceive in their environment (Lüthje \& Franke, 
2003). The innate qualifications entrepreneurs have can be developed, supported or hampered in the process of life (Timmons \& Spinelli, 2003). The factors that affect individuals' choice of entrepreneurship are: its financial rewards, freedom, self-confidence and feeling of success as a result of self-employment, freedom to make innovation and respect of the society for entrepreneurs (Wickham, 2006). Entrepreneurship is affected more from psychosocial reasons than economic reasons (Erdoğmuş, 2000). Concordantly, psychological factors like need for success, control focus, tendency to take risk, undertaking uncertainty, self confidence and innovativeness come to the fore as determinants of entrepreneurship (Aytaç, 2006).

Entrepreneurship can be explained with the values people have and prefer. It is rather difficult to define the concept of value with a standard expression. Values are generalized principles that are accepted by the members of the society for the operation and maintenance of the society (Avşaroğlu, 2012). Value are generalized moral principles or beliefs that are accepted to be correct and necessary by the members of the society or the group for the operation and maintenance of the society and that reflect their feelings, ideas, objectives and interests (Kızılçelik \& Erjem, 1992). Values are social representatives of objectives that are regarded to be principles that direct people's lives and motivate them for life (Rohan, 2000). Researchers like Levy and Guttman emphasize that values are a subset of behaviors (Elizur, 1996: p. 25). Many researchers define value as the basic belief behind the idea that motives people. Therefore, values guide people's acts and behaviors. In other words, what an individual does and how s/he does it are shaped by the values s/he has (Kenny, 1994: p. 17).

Individuals vary in terms of the importance or priority they attach to values and the value priorities of the individual are mostly influenced by the dominant values of the culture $s /$ he lives in. Individual's values are accepted as the product of the culture $\mathrm{s} /$ he lives in. Therefore, values and beliefs play a determining role in human behavior and individual's performance at individual level, and at organizational levels they determine the performance of the organization (Ergün, 2003). Meanwhile, humanistic values make individuals' psychological needs more understandable. This also contributes to the realization of their potentials and success (Stallard \& Pankau, 2008).

Individuals seek to lead their lives in an environment built around his/own and society's values (Turan \& Aktan, 2008). Individuals can change the values they have in the interaction process. In this process, school life of the individual is of great importance.

When entrepreneurship tendency is examined in terms of values, it is pointed out that entrepreneurs attach importance to independence, loyalty, success and goal directedness (Naktiyok \& Timuroğlu, 2009). Values which are regarded to be principles that guide people's lives and means for expressing human needs shape current and means that motivate standard and ideal behavior patterns, learned rules, behavioral sanction, functions as a plan for decision making and conflict resolution (Russell, 2001: pp. 76-77; Kenny, 1994: p. 17). The need for success, which is a new value, is one of the motivational factors that affect entrepreneurship intention (Douglas \& Fitzsimmons, 2005: p. 2). In his/her studies on entrepreneurship Schumpeter emphasized dynamic and static behavior types in parallel with hedonistic motives and stated that these motives affected behaviors (Ebner, 2006: p. 504). Universal thinking proposes the protection of the wealth of humanity and nature, and points out the need to accept and understand it. The values in this dimension are equality, a peaceful and beautiful world, nature friendliness, social justice, freedom of thought, protection of environment and internal harmony (Schwartz \& Boehnke, 2004: p. 239). Lee and Peterson argue that universal thinking contributes to entrepreneurship (Elam, 2006: p. 6). In contrast to those who advocate that entrepreneurship is motivated by economic and socio-biological factors, it is also argued that it is motivated by benevolence and altruism (Montanye, 2006: p. 552). It is noted that entrepreneurship efforts that do not have cultural values that reveal and support social existence and safety are bound to lead to failure (Ceylan \& Demircan, 2002: p. 3). As it can be understood from these explanations, the values individuals have can explain their entrepreneurship.

The determination of the factors that cause people start a new business by taking social, psychological and financial risks is important for understanding entrepreneurship, which underlies economic development. Entrepreneurship tendency can be explained with humanistic values people prefer because values provide guidelines for people to choose and realize their social roles. Thus, people determine the requirements and expectations of various roles with certain values (Fichter, 1990).

The aim of this study is to examine individuals' entrepreneurship tendency in terms of humanistic values they prefer. With this aim in mind, answers for the following questions were sought:

- Is there a significant relation between the entrepreneurship tendencies of people and humanistic values?

- Do the humanistic values people prefer explain entrepreneurship tendencies significantly?

\section{Method}

The model of the study, the universe and sample, means of data collection and statistical methods used for the analysis of data were reported in this section.

\section{The Model of the Study}

This study was carried out with the relational screening model. The study model includes two basic variables: dependent and independent variable. The humanistic values the individuals in the study group prefer are the independent variables in the study model. The entrepreneurship tendencies of the individuals in the study group are the dependent variables in the study model. The relation between humanistic values of the individuals in the study group and the level humanistic values explain entrepreneurship was examined.

\section{The Study Group}

The study group of the study is composed of 482 students who were selected with random sampling method among university students attending various faculties at Selçuk University in 2012. While 248 of the students were male, 234 were female. Meanwhile, $44 \%$ of the individuals studied at quantitative departments, $42 \%$ studied at verbal departments and $16 \%$ studied at sports and arts related departments.

\section{Means of Data Collection}

In the study, personal information form was used to obtain personal information about the participants. To measure value 
preferences of the individuals in life, Schwartz List of Values was used. The Entrepreneurship Scale, which was developed by Yilmaz and Sünbül (2009), was used to measure their entrepreneurship tendencies.

\section{Entrepreneurship Scale}

In order to measure individuals' entrepreneurship tendencies, the entrepreneurship scale developed by Y1lmaz and Sünbül (2009) was used. The scale is composed of 36 items. The scale is a one-dimensional and likert type scale. The Cronbach Alfa reliability coefficient is 0.90 . The reliability coefficient of the scale for the study sample was calculated to be 0.92 .

\section{Schwartz List of Values (SLV)}

Schwartz List of Values (SDL) is composed of 57 values. A total of fifty-seven values were grouped under 10 sub-dimensions. These sub-dimensions are listed as follows: power, success, hedonism, stimulation, self-auditing, universality, benevolence, conventionalism, harmony and safety. In a study by Bacanlı (1999), Kuşdil and Kağıtçıbaşı (2000), the reliability coefficients for value dimensions were determined to be 0.66 for success, 0.54 for hedonism, 0.70 for stimulation, 0.77 for universality, 0.76 for benevolence, 0.63 for conventionalism, 0.51 for harmony, 0.59 for safety, 0.75 for power and 0.69 for selfauditing.

\section{Data Analysis}

The relation between the dimensions of humanistic values and entrepreneurship was tested using Pearson product-moment correlation technique. Multiple regression technique was administrated to determine the level humanistic values explain entrepreneurship. The significance level is accepted to be 0.05 in the analysis of data (Balc1, 2004). Therefore, significance level accepted for this study was 0.05 .

\section{Results and Discussion}

In this section, the results of the statistical analyses administrated in line with the objectives of the study and their discussions are presented.

The relation between humanistic values and entrepreneurship tendencies was tested with Pearson product moment correlation technique and the results are given in Table $\mathbf{1 .}$

When Table 2 is examined, it is understood that there is a significant relation between entrepreneurship and the following sub-dimensions of humanistic values people prefer: power, success, hedonism, stimulation, self-auditing, universality, benevolence, conventionalism, harmony and safety.

The explanation level of the humanistic values individuals prefer for entrepreneurship tendency was tested with multiple regression analysis technique. The results are given in Table 2.

When Table 2 is examined, it is seen that the humanistic values individuals in the study group prefer significantly affect their entrepreneurship tendencies $(\mathrm{F}=15,27 ; p<0.01)$. It was seen that ten dimensions of the humanistic values individuals prefer explain $24 \%$ of the variety in their entrepreneurship tendencies. When the levels of the effect of humanistic values are examined, power, hedonism, stimulation, self-auditing, universality, conventionalism and trustworthiness values had significant effect on entrepreneurship. The humanistic value dimen-
Table 1.

The correlation between humanistic values and entrepreneurship.

\begin{tabular}{cc}
\hline & Entrepreneurship \\
\cline { 2 - 2 } Dimension of Humanistic Value & $\mathrm{r}$ \\
\hline Power & $0.267^{* *}$ \\
Success & $0.299^{* *}$ \\
Stimulation & $0.105^{*}$ \\
Self-auditing & $0.367^{* *}$ \\
Universality & $0.328^{* *}$ \\
Benevolence & $0.265^{* *}$ \\
Conventionalism & $0.235^{* *}$ \\
Harmony & $0.119^{*}$ \\
Safety & $0.181^{* *}$ \\
\hline
\end{tabular}

Note: ${ }^{* *} p<0.01 ;{ }^{*} p<0.05$.

Table 2.

Effects of humanistic values on entrepreneurship.

\begin{tabular}{|c|c|c|c|c|c|c|}
\hline $\begin{array}{c}\text { Independent } \\
\text { Variable }\end{array}$ & $\mathrm{R}^{2}$ & $\mathrm{~F}$ & $p$ & $\begin{array}{c}\text { Dimension of } \\
\text { Humanistic } \\
\text { Values }\end{array}$ & $\mathrm{t}$ & $p$ \\
\hline \multirow{11}{*}{$\begin{array}{l}\text { Humanistic } \\
\text { Values }\end{array}$} & \multirow{10}{*}{0.236} & \multirow{10}{*}{15.271} & \multirow{10}{*}{0.000} & Power & 3.424 & 0.001 \\
\hline & & & & Success & 0.930 & 0.353 \\
\hline & & & & Hedonism & -2.642 & 0.009 \\
\hline & & & & Stimulation & 5.531 & 0.000 \\
\hline & & & & Self-Auditing & 3.026 & 0.003 \\
\hline & & & & Universality & 2.873 & 0.004 \\
\hline & & & & Benevolence & 1.757 & 0.080 \\
\hline & & & & Conventionalism & -2.255 & 0.025 \\
\hline & & & & Harmony & -1.346 & 0.179 \\
\hline & & & & Safety & -4.295 & 0.000 \\
\hline & \multicolumn{5}{|c|}{ Dependent Variable: Entrepreneurship } & \\
\hline
\end{tabular}

Note: ${ }^{* *} p<0.01 ;{ }^{*} p<0.05$.

sions which did not have a significant effect on entrepreneurship are success, benevolence and harmony.

\section{Discussion}

When the results of the study were examined, it was seen that there is a significant relation between individuals' entrepreneurship tendency and humanistic values they preferred. According to the results of the study, it can be considered that entrepreneurship tendencies of individuals who prefer humanistic values are dominant. The question of whether personality or social environment is more influential on the emergence of entrepreneurship has been discussed for a long period of time. Those who emphasize personality give weight to psychological characteristics. Personality characteristics linked with entrepreneurship are risk taking, need for success and control focus 
(Aytaç, 2006: p. 142; Gürol \& Atsan, 2006). It can be argued that personality characteristics are related with humanistic values. Especially, success, stimulation and self-auditing subdimensions of humanistic values are related with being competent, being ambitious, being influential, being brave, leading a flexible and exciting life, being free, being able to choose his/ her objectives, being independent and having self-esteem. The aforementioned personality characteristics risk taking, need for success and control focus which are related with entrepreneurship are accepted to be related with success, stimulation and self-auditing, which are among humanistic values. In a study by McCabe (2012), it was determined that the values people preferred support social entrepreneurship. This result tallies with the results of this study. In some studies, it was found that values and beliefs of individuals affect their entrepreneurship (Llano, 2006: p. 22; Kellermanns \& Eddleston, 2006; Tan et al., 2003: p. 2; Davidsson \& Wiklund, 1997: p. 188). It can be thought that the results of these studies support the study results. As a result of a study by Bhandari on students in India, no relation was found between social status and prestige and entrepreneurship (Bhandari, 2006: p. 177). This result does not comply with the result of the current study.

When the results of the current study are examined again, the humanistic values people prefer explain $24 \%$ of variability in entrepreneurship tendency. This is a rather high rate. When the results are examined in terms of the sub-dimensions of humanistic values, it is seen that while power, hedonism, stimulation, self-auditing universality, conventionalism and safety explain entrepreneurship significantly, the sub-dimensions of success benevolence and harmony do not explain it at significant level. The commonly agreed upon personality characteristics determined by psychologist to be related with entrepreneurship tendency are openness, responsibility, extraversion, harmony and emotional balance (Aytaç, 2006: p. 142; Gürol \& Atsan, 2006: p. 28). Extraversion and openness, the personality characteristics accepted to be related with entrepreneurship, can be argued to be related with universality, power, and safety values among humanistic values. Extraversion and openness are explained with sensation, adventure, extraordinary ideas, imagination, behaving responsibly and being determined for success and acting in a planned way rather than instinctively. The universality dimension of humanistic values is related with social justice, living in a peaceful and beautiful world, being virtuous, protecting environment, being open minded, equality, integration with nature and inner peace tendencies. The individuals who prefer this value can be considered to be more extravert and open. Again, power is explained with having social power and authority, being rich and saving his image in the society. The value of power can increase these features, individuals' extraversion and openness. The responsibility characteristic which explains entrepreneurship can be assumed to be safety and conventionalism dimensions of humanistic values because safety value is related with individuals' feeling of national safety and loyalty, returning the favor, caring for social order and family safety, being healthy and clean. The individuals who prefer conventionalism also prefer accepting life as it comes, being moderate, faithful and modest, respect for customs, privacy and personal rights. As it can be seen, conventionalism and safety can affect responsibility acts positively. The last personality character which is regarded to be related with entrepreneurship is emotional balance. Emotional balance can be considered to be related with hedonism and self-auditing dimensions of hu- manistic values. Individuals who prefer hedonism seek to get pleasure out of life and fond of their wants. The value of selfauditing is explained with being creative, free and independent, being able to choose one's own goals and having self-esteem. Individuals with stimulation value are brave, lead a flexible and exciting life. When the aforementioned characteristics are considered with regard to individuals who prefer hedonism, stimulation and self-auditing values, it can be argued that these people can preserve their emotional balance. When sub-dimensions of humanistic values are considered based on the explanations above, it can be concluded that power, hedonism, stimulation, self-auditing universality, conventionalism and safety sub-dimensions are supposed to explain entrepreneurship tendency. In a study by Ersoy (2010), it was revealed that entrepreneurship tendency is related with religious belief and religious faiths contributed to entrepreneurship tendencies. This result supports the results of the current study that conventionalism value contributed to entrepreneurship. In a study by Kuvan (2007), a relation was found between life values and entrepreneurship tendencies of people, which also supports the results of this study. In their study Peay and Dyer pointed out that entrepreneurs are motivated by both social and individual power needs (Peay \& Dyer, 1989: p. 52). A significant and positive relation between richness, which is included in the value of power, and entrepreneurship was found (Hurst \& Lusardi, 2004: p. 320). These results can be considered to comply with the results of the current study.

When the results of the study are examined with regard to the explanatory power of humanistic values for entrepreneurship tendencies, it was determined that success, benevolence and harmony humanistic value dimension did not explain entrepreneurship tendency significantly. The value of success can be considered to be a result of entrepreneurship activities because it is more related with being a competent and influential person. This tendency can be considered to come into being as a result of success in certain activities. The individuals who prefer the value of benevolence are inclined to be merciful, gracious and loyal, which can be argued to positively influence initiation and competitiveness that are characteristics related with entrepreneurship. The value of harmony is related with being obedient. So, it can be considered to not to comply with such characteristics of entrepreneurship tendency like innovative thinking skill, openness to change or accepting change (Yurtseven, 2007: p. 67; Tekin, 2005: p. 47; Kaya, 2007: pp. 46-47; Öznur, 2007). As it can be understood from these explanations, success, benevolence and harmony humanistic values are not expected to explain entrepreneurship tendency.

As a result of the study, it was revealed that there is a significant relation between the humanistic values people prefer and entrepreneurship and those humanistic values explain entrepreneurship tendency. Based on these results, the following suggestions can be made. Considering that values are gained through education, the attainments required for the courses in higher education can be related with values. In further studies, researchers can examine the relation between entrepreneurship and other personality characteristics by using humanistic values as a mediating variable.

\section{REFERENCES}

Avsaroğlu, S. (2012). Value preferences of pre-service teachers: A comparison of Turkey, Azerbaijan and Kyrgyzstan. Energy Educa- 
tion Science and Technology Part B: Social and Educational Studies, 4, 733-742.

Aytaç, Ö. (2006). Entrepreneurship: Socio-cultural perspective. Dumlupinar Üniversitesi Sosyal Bilimler Dergisi, 15, 139-160.

Balc1, A. (2004). A research of social sciences. Ankara: Pegem Yayıncllik.

Bhandari, N. C. (2006). Intention for entrepreneurship among students in India. Journal ofEntrepreneurship, 15, 169-179. doi:10.1177/097135570601500204

Bridge, S., O’Neill, K., \& Cromine, S. (1998). Understanding enterprise, entrepreneurship and small business. London: Macmillan Business.

Ceylan, A., \& Demircan, N. (2002). A study into relationship between success, power, intimacy needs and characteristics of entrepreneurs in small and medium sized companies: Small and medium sized companies in 21 st centuries, problems, opportunities and suggestions for solutions. Doğu Akdeniz Üniversitesi İşletme Fakültesi, 1-19.

Çetindamar, D. (2002). Entrepreneurship in Turkey. İstanbul: Tüsiad Yayınları.

Davidsson, P., \& Wiklund, J. (1997). Values, beliefs and regional variations in new firm formation rates. Journal of Economic Psychology, 18, 179-199. doi:10.1016/S0167-4870(97)00004-4

Douglas, E. J., \& Fitzsimmons, J. R. (2005). Entrepreneurial intentions towards individual vs. corporate entrepreneurship. Seaanz Conference, Armidale, September 2005.

Ebner, A. (2006). Institutions, entrepreneurship and the rationale of government: An outline of the Schumpeterian theory of the state. Journal of Economic Behavior \& Organization, 59, 497-515. doi:10.1016/j.jebo.2005.06.003

Elam, A. B. (2006). Gender and entrepreneurship across 28 countries: A multilevel analysis using gem data. Doctoral Dissertation, Chapel Hill: The University of North Carolina.

Elizur, D. (1996). Work values and commitment. International Journal of Manpower, 17, 25-30. doi:10.1108/01437729610119496

Elizur, D., Borg, I., Hunt, R., \& Beck, I. M. (1991). The structure of work values: A cross cultural comparison. Journal of Organizational Behavior, 12, 21-38. doi:10.1002/job.4030120103

Erdoğmuş, N. (2000). A research into carrier development of entrepreneur businessmen via analyzing autobiographies. Ulusal Yönetim ve Organizasyon Kongresi, 8, 95-108.

Ergün, E. (2003). A practice concerning effects of cultural characteristics in enterprises on organizational performance. Unpublished Doctoral Dissertation, Gebze: İleri Teknoloji Enstitüsü.

Ersoy, H. (2010). Effect of environment on the choice of entrepreneurship. Organizasyon and Yönetim Bilimleri Dergisi, 2, 145-158.

Fichter, J. (1990). What is sociology? Konya: Selçuk Üniversitesi Yayinlari.

Gürol, Y., \& Atsan, N. (2006). Entrepreneaurial characteristics amongst university students: Some insights for entrepreneurship education and training in Turkey. Education and Training, 48, 25-38. doi:10.1108/00400910610645716

Hisrich, R. D., \& Michael, P. P. (1998). Entrepreneurship. New York: The McGraw Hill Book Co.

Hurst, E., \& Lusardi, A. (2004). Liquidity constraints, household wealth and entrepreneurship. Journal of Political Economy, 112, 319-347. doi: $10.1086 / 381478$

Iredale, N., \& Motsa, A. (2002). Developing enterprising behavior. Enterprise Impact News, 14, 1-4.

Karahan, M., \& Ulusoy, İ. (2010). A study into characteristics of entrepreneurship in the city of Hatay. EKEV Akademi Dergisi, 14, 367379.

Kaya, A. (2007). Entrepreneurship and SEM management in the light of informatics and communication. Konya: Eğitim Kitabevi.

Kellermanns, F. W., \& Kimberly, A. E. (2006). Corporate entrepreneurship in family firms: A Family perspective. Entrepreneurship Theory and Practice, 809-830. doi:10.1111/j.1540-6520.2006.00153.x

Kenny, T. (1994). From vision to reality through values. Management
Development Review, 7, 17-20. doi:10.1108/09622519410060375

Kızılçelik, S., \& Erjem, Y. (1992). Annotated dictionary of sociological terms. Konya: Günay Ofset.

Kuşdil, M. E., \& Kağıtçıbaşı, Ç. (2000). Value orientations of Turkish teachers and Schwartz value theory. Türk Psikoloji Dergisi, 15, 5976.

Llano, J. A. (2006). The university environment and academic entrepreneurship: A behavioral model for measuring environment success. Work Paper, 1-27.

Lüthje, C., \& Franke, N. (2003). The making of an entrepreneur: Testing a model of entrepreneurial intent among engineering students at MIT. $R$ \& D Management, 33, 135-147. doi:10.1111/1467-9310.00288

McCabe, L. A. (2012). Human values of entrepreneurship: An empirical analysis of the human values of social and traditional entrepreneurs. Doctoral Dissertation, Regent University.

Montanye, J. A. (2006). Entrepreneurship. The Independent Review, 10, 549-571.

Naktiyok, A., \& Timuroğlu, M. K. (2009). The effect of students' motivational values on their intentions of entrepreneurship: A practice. Atatürk Üniversitesi İktisadi ve İdari Bilimler Dergisi, 23, 85-103.

Ofsted-Better Education and Care (2005). Developing enterprising young people.

http://www.ofsted.gov.uk/publications/index.cfm?fuseaction=pubs.di splayfile\&id=4093\&type $=$ pdf

Ögüt, A., Şendoğdu, A., \& Yılmaz, N. (2006). The principals of information management in terms of typology of informatics' entrepreneurship. Bişkek: Türkiye Manas Üniversitesi İ.İ.B.F. Uluslararası Girişimcilik Kongresi.

Özkul, G., \& Dulupçu, M. A. (2007). The effects of personal development on types of entrepreneurs: A study in the cities of Antalya and Isparta. Girişimcilik ve Kalkınma Dergisi, 2, 67-92.

Peay, T. R., \& Dyer, W. G. (1989). Power orientation of entrepreneurs and succession planning. Journal of Small Business Management, 27, 47-52.

Robbins, S., \& Coulter, M. (1999). Management. Upper Saddle River, NJ: Prentice Hall.

Rohan, M. J. (2000). A rose by any name? The values construct. Personality and Social Psychology Review, 4, 255-277. doi:10.1207/S15327957PSPR0403 4

Russell, R. F. (2001). The role of values in servant leadership. Leadership \& Organization Development Journal, 22, 76-83. doi:10.1108/01437730110382631

Schwartz, S. H., \& Klaus, B. (2004). Evaluating the structure of human values with confirmatory factor analysis. Journal of Research in Personality, 38, 230-255. doi:10.1016/S0092-6566(03)00069-2

Smilor, W. R., \& Sexton, D. I. (1996). Leadership and entrepreneurship: Personal and organizational development in entrepreneurial ventures. London: Quorum Books.

Tan, W.-L., Leung, D. H. Y., \& Begley, T. (2003). The influence of political factors on entrepreneurship intentions. Working Paper, 12, 110.

Timmons, J. A., \& Spınellı, S. (2003). New venture creation/entrepreneurship for the 21st century. Singapore City: McGraw-Hill.

Turan, S., \& Aktan, D. (2008). Existing and expecting social values in the school life. Türk Eğitim Bilimleri Dergisi, 6, 227-259.

Turan, M., \& Nacimudinova, S. (2006). The change indication of personality of entrepreneurs between cultures: A comparative research on Turkish and Kyrgyz entrepreneurs. Bişkek: Türkiye Manas Üniversitesi İ.̇.B.F. Uluslararası Girişimcilik Kongresi.

Wickham, P. A. (2006). Strategic entrepreneurship. Essex, UK: Prentice Hall.

Yılmaz, E., \& Sünbül, A. M. (2009). The development of entrepreneurship scale for university students. Selçuk Üniversitesi Sosyal Bilimler Enstitüsü Dergisi, 21, 195-203.

Yurtseven, H. R. (2007). Entrepreneurship—Founding a small sized company. Ankara: Detay Yayıncılık. 